\title{
Upaya Meningkatkan Prestasi Belajar Pendidikan Agama Islam Dengan Menerapkan Model Pengajaran Kolaborasi Pada Siswa Kelas III Tahun Pelajaran 2016/2017
}

\author{
Aminah \\ SDN 1 Mambalan Lombok Barat
}

\begin{abstract}
Abstrak. Tujuan dalam penelitian ingin mengetahui peningkatan belajar agama islam dengan diterapkannya metode pengajaran kalaborasi. Metode dalam penelitian adalah Penelitian tindakan kelas. Berdasarkan hasil penelitian yang telah dilakukan selama tiga siklus, hasil seluruh pembahasan serta analisis yang telah dilakukan dapat disimpulkan sebagai berikut: Model pengajaran kolaborasi dapat meningkatkan kualitas pembelajaran PAI. Pembelajaran model Kolaborasi memiliki dampak positif dalam meningkatkan prestasi belajar siswa yang ditandai dengan peningkatan ketuntasan belajar siswa dalam setiap siklus, yaitu siklus I $(68,18 \%)$, siklus II $(79,01 \%)$, siklus III $(86,36 \%)$. Model pengajaran kolaborasi dapat menjadikan siswa merasa dirinya mendapat perhatian dan kesempatan untuk menyampaikan pendapat, gagasan, ide dan pertanyaan.
\end{abstract}

Kata Kunci: Prestasi Belajar, Agama Islam, Model Pengajaran Kolaborasi,

\section{PENDAHULUAN}

Kegiatan belajar mengajar yang berlangsung telah terjadi interaksi yang bertujuan. Guru dan anak didiklah yang menggerakannya. Interaksi yang bertujuan itu disebabkan gurulah yang memaknainya dengan menciptakan lingkungan yang bernilai edukatif demi kepentingan anak didik dalam belajar. Guru ingin memberikan layanan yang terbaik bagi anak didik, dengan menyediakan lingkungan yang menyenangkan dan menggairahkan. Guru berusaha menjadi pembimbing yang baik dengan peranan yang arif dan bijaksana, sehingga tercipta hubungan dua arah yang harmonis antara guru dengan anak didik.

Ketika kegiatan belajar itu berproses, guru harus dengan ikhlas dalam bersikap dan berbuat, serta mau memahami anak didiknya dengan segala konsekuensinya. Semua kendala yang terjadi dan dapat menjadi penghambat jalannya proses belajar mengajar, baik yang berpangkal dari perilaku anak didik maupun yang bersumber dari luar anak didik, harus guru hilangkan, dan bukan membiarkannya. Karena keberhasilan belajar mengajar lebih banyak ditentukan oleh guru dalam mengelola kelas.
Guru yang memandang anak didik sebagai pribadi yang berbeda dengan anak didik lainnya akan berbeda dengan guru yang memandang anak didik sebagai makhluk yang sama dan tidak ada perbedaan dalam segala hal. Maka adalah penting meluruskan pandangan yang keliru dalam menilai anak didik. Sebaiknya guru memandang anak didik sebagai individu dengan segala perbedaannya, sehingga mudah melakukan pendekatan dalam pengajaran. Dalam perkembanganya pendidikan memiliki peran yang bersifat universal. Isnaini (2018) Pendidikan memainkan peranan penting dalam hidup dan kehidupan bermasyarakat. Isnaini (2012) Perkembangan dunia pendidikan tinggi mempunyai dampak terhadap proses pendidikan.

Kualitas pembelajaran ditentukan oleh interaksi komponen-komponen dalam sistemnya. Yaitu tujuan, bahan ajar (materi), anak didik, sarana, media, metode, partisipasi masyarakat, performance sekolah, dan evaluasi pembelajaran (Moh, Shochib, 1998). Performance sekolah, dan evaluasi pembelajaran (Moh, Shochib, 1998). Optimalisasi komponen ini, menentukan kualitas (proses dan produk) pembelajaran. Upaya yang dapat dilakukan oleh 
pendidik adalah melakukan analisis tentang karakteristik setiap komponen dan mensinkronisasikan sehingga ditemukan konsistensi dan keserasian di antaranya untuk tercapainya tujuan pembelajaran. Karena pembelajaran mulai dari perencana, pelaksanaan dan evaluasinya senantiasa merujuk pada tujuan yang diharapkan untuk dikuasai atau dimiliki oleh anak didik baik instructional effect (sesuai dengan tujuan yang dirancang) maupun nurturrant effect (dampak pengiring) (Moch. Shochib: 1999).

Realisasi pencapaian tujuan tersebut, terdapat kegiatan interaksi belajar mengajar terutama yang terjadi di kelas. Dengan demikian, kegiatannya adalah bagaimana terjadi hubungan antara guru/bahan ajar yang didesain dan dengan anak didik. Interaksi ini merupakan proses komunikasi penyampaian pesan pembelajaran. Hal ini sejalan dengan yang dikemukakan Arief $\mathrm{S}$ Sadiman yang menyatakan proses belajar mengajar pada hakekatnya adalah proses interaksi yaitu proses penyampaian pesan melalui saluran media/teknik/ metode ke penerima pesan. (Arief S, Sadiman, dkk, 1996:13).

Sejalan dengan inovasi pembelajaran akhir-akhir ini termasuk di Sekolah Dasar, yaitu: Kolaborasi. Interaksi belajar mengajarnya menuntut anak didik untuk aktif, kreatif dan senang yang melibatkan secara optimal mental dan fisik mereka. Tingkat keaktifan, kreatifitas, dan kesenangan mereka dalam belajar merupakan rentangan kontinum dari yang paling rendah sampai yang paling tinggi.

Interaksi belajar mengajar idealnya mampu membelajarkan anak didik berdasarkan problem based learning, authentic instruction, inquiry based learning, project based learning, service learning, and cooperative learning. Pola interaksi yang mampu mengemas hal tersebut dapat mengubah paradigma pembelajaran aktif menjadi paradigma pembelajaran reflektif.

Dengan interaksi pembelajaran reflektif dapat membuat anak didik untuk menjadikan hasil belajar sebagai referensi refleksi kritis tentang dampak ilmu pengetahuan dan teknologi terhadap masyarakat; mengasah kepedulian sosial, mengasah hati nurani, dan bertanggungjawab terhadap karirnya kelak. Kemampuan ini dimiliki anak didik, karena dengan pola interaksi pembelajaran tersebut, dapat membuat anak didik aktif dalam berfikir (mind-on), aktif dalam berbuat (hand-on), mengembangkan kemampuan bertanya, mengembangkan kemampuan berkomunikasi, dan membudayakan untuk memecahkan permasalahan baik secara personal maupun sosial.

Agar hasil ini dapat optimal, guru dituntut untuk mengubah peran dan fungsinya menjadi fasilitator, mediator, mitra belajar anak didik, dan evaluator. Ini berarti, guru harus menciptakan interaksi pembelajaran yang demokratis dan dialogis antara guru dengan anak didik, dan anak didik dengan anak didik (Moh. Shochib: 1999; dan Paul Suparno dkk: 2001).

Dengan interaksi pembelajaran yang mengemas nilai-nilai tersebut dapat membuat pembelajaran lingking (link and math atau life skill) dan delinking (pemutusan lingkungan negatif), diversifikasi kurikulum, pembelajaran kontekstual, kurikulum berbasis kompetensi, dan otonomi pendidikan pada tingkat sekolah taman kanak-kanak dengan manajemen berbasis sekolah, dan bertujuan untuk mengupayakan fondasi dan mengembangkan anak untuk memiliki kemampuan yang utuh yang disebut: Pendidikan Anak Seutuhnya (PAS).

Berhasilnya tujuan pembelajaran ditentukan oleh banyak faktor diantaranya adalah faktor guru dalam melaksanakan proses belajar mengajar, karena guru secara langsung dapat mempengaruhi, membina dan meningkatkan kecerdasan serta keterampilan siswa. Untuk mengatasi permasalahan di atas dan guna mencapai tujuan pendidikan secara maksimal, peran guru sangat penting dan diharapkan guru mampu menyampaikan semua mata pelajaran yang tercantum dalam proses pembelajaran secara tepat dan sesuai dengan konsep-konsep mata pelajaran yang akan disampaikan. 
Dengan menyadari kenyataan tersebut di atas, maka dalam penelitian ini penulis mengambil judul "Upaya Meningkatkan Prestasi Belajar Pendidikan Agama Islam Dengan Menerapkan Model Pengajaran kolaborasi Pada Siswa III Tahun Pelajaran 2016/2017

\section{METODOLOGI PENELITIAN}

Penelitian ini merupakan penelitian tindakan (action research), karena penelitian dilakukan untuk memecahkan masalah pembelajaran di kelas. Penelitian ini juga termasuk penelitian deskriptif, sebab menggambarkan bagaimana suatu teknik pembelajaran diterapkan dan bagaimana hasil yang diinginkan dapat dicapai.

Menurut Sukidin dkk (2002:54) ada 4 macam bentuk penelitian tindakan, yaitu: (1) penelitian tindakan guru sebagai peneliti, (2) penelitian tindakan kolaboratif, (3) penelitian tindakan simultan terintegratif, dan penelitian tindakan sosial eksperimental.

Keempat bentuk penelitian tindakan di atas, ada persamaan dan perbedaannya. Menurut Oja dan Smulyan sebagaimana dikutip oleh Kasbolah, (2000) (dalam Sukidin, dkk. 2002:55), ciri-ciri dari setiap penelitian tergantung pada: (1) tujuan utamanya atau pada tekanannya, (2) tingkat kolaborasi antara pelaku peneliti dan peneliti dari luar, (3) proses yang digunakan dalam melakukan penelitian, dan (4) hubungan antara proyek dengan sekolah.

Dalam penelitian ini menggunakan bentuk guru sebagai peneliti, dimana guru sangat berperan sekali dalam proses penelitian tindakan kelas. Dalam bentuk ini, tujuan utama penelitian tindakan kelas ialah untuk meningkatkan praktik-praktik pembelajaran di kelas. Dalam kegiatan ini, guru terlibat langsung secara penuh dalam proses perencanaan, tindakan, observasi, dan refleksi. Kehadiran pihak lain dalam penelitian ini peranannya tidak dominan dan sangat kecil.

Penelitian ini mengacu pada perbaikan pembelajaran yang berkesinambungan. Kemmis dan Taggart (1988:14) menyatakan bahwa model penelitian tindakan adalah berbentuk spiral. Tahapan penelitian tindakan pada suatu siklus meliputi perencanaan atau pelaksanaan observasi dan refleksi. Siklus ini berlanjut dan akan dihentikan jika sesuai dengan kebutuhan dan dirasa sudah cukup.

\section{A. Tempat, Waktu dan Subyek Penelitian 1.Tempat Penelitian}

Tempat penelitian adalah tempat yang digunakan dalam melakukan penelitian untuk memperoleh data yang diinginkan. Penelitian ini bertempat di SDN 1 Mambalan Tahun pelajaran 2016-2017

2.Waktu Penelitian

Waktu penelitian adalah waktu berlangsungnya penelitian atau saat penelitian ini dilangsungkan. Penelitian ini dilaksanakan pada bulan Maret semester genap 2016-2017

3. Subyek Penelitian

Subyek penelitian adalah siswa-siswi kelas III tahun pelajaran 2016-2017 pada pokok bahasan Sholat.

\section{B. Rancangan Penelitian}

Menurut pengertiannya penelitian tindakan adalah penelitian tentang hal-hal yang terjadi di masyarakat atau sekelompok sasaran, dan hasilnya langsung dapat dikenakan pada masyarakat yang bersangkutan (Arikunto, Suharsimi 2002:82). Ciri atau karakteristik utama dalam penelitian tindakan adalah adanya partisipasi dan kolaborasi antara peneliti dengan anggota kelompok sasaran. Penelitian tindakan adalah satu strategi pemecahan masalah yang memanfaatkan tindakan nyata dalam bentuk proses pengembangan inovatif yang dicoba sambil jalan dalam mendeteksi dan memecahkan masalah. Dalam prosesnya pihak-pihak yang terlibat dalam kegiatan tersebut dapat saling mendukung satu sama lain.

Sedangkan tujuan penelitian tindakan harus memenuhi beberapa prinsip sebagai berikut:

1. Permasalahan atau topik yang dipilih harus memenuhi kriteria, yaitu benar-benar nyata dan penting, menarik perhatian dan mampu ditangani serta dalam jangkauan 
kewenangan peneliti untuk melakukan perubahan.

2. Kegiatan penelitian, baik intervensi maupun pengamatan yang dilakukan tidak boleh sampai mengganggu atau menghambat kegiatan utama.

3. Jenis intervensi yang dicobakan harus efektif dan efisien, artinya terpilih dengan tepat sasaran dan tidak memboroskan waktu, dana dan tenaga.

4. Metodologi yang digunakan harus jelas, rinci, dan terbuka, setiap langkah dari tindakan dirumuskan dengan tegas sehingga orang yang berminat terhadap penelitian dapat mengecek setiap hipotesis dan pembuktiannya.

5. Kegiatan penelitian diharapkan dapat merupakan proses kegiatan yang berkelanjutan (on-going), mengingat bahwa pengembangan dan perbaikan terhadap kualitas tindakan memang tidak dapat berhenti tetapi menjadi tantangan sepanjang waktu. (Arikunto, Suharsimi, 2002:82-83).

Sesuai dengan jenis penelitian yang dipilih, yaitu penelitian tindakan, maka penelitian ini menggunakan model penelitian tindakan dari Kemmis dan Taggart (dalam Arikunto, Suharsimi, 2002:83), yaitu berbentuk spiral dari siklus yang satu ke siklus yang berikutnya. Setiap siklus meliputi planning (rencana), action (tindakan), observation (pengamatan), dan reflection (refleksi). Langkah pada siklus berikutnya adalah perencanaan yang sudah direvisi, tindakan, pengamatan, dan refleksi. Sebelum masuk pada siklus I dilakukan tindakan pendahuluan yang berupa identifikasi permasalahan. Siklus spiral dari tahap-tahap penelitian tindakan kelas dapat dilihat pada gambar berikut.

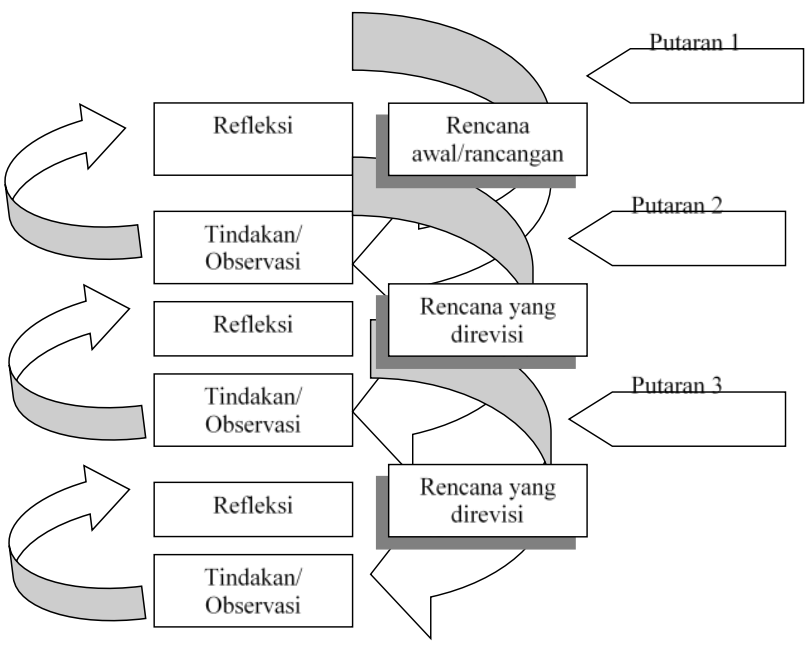

Gambar 3.1 Alur PTK

1. Rancangan/rencana awal, sebelum mengadakan penelitian peneliti menyusun rumusan masalah, tujuan dan membuat rencana tindakan, termasuk di dalamnya instrumen penelitian dan perangkat pembelajaran.

2. Kegiatan dan pengamatan, meliputi tindakan yang dilakukan oleh peneliti sebagai upaya membangun pemahaman konsep siswa serta mengamati hasil atau dampak dari diterapkannya pengajaran kontekstual model pengajaran berbasis masalah.

3. Refleksi, peneliti mengkaji, melihat dan mempertimbangkan hasil atau dampak dari tindakan yang dilakukan berdasarkan lembar pengamatan yang diisi oleh pengamat.

4. Rancangan/rencana yang direvisi, berdasarkan hasil refleksi dari pengamat membuat rancangan yang direvisi untuk dilaksanakan pada siklus berikutnya.

Observasi dibagi dalam tiga siklus, yaitu siklus 1, 2, dan seterusnya, dimana masing siklus dikenai perlakuan yang sama (alur kegiatan yang sama) dan membahas satu sub pokok bahasan yang diakhiri dengan tes formatif di akhir masing putaran. Siklus ini berkelanjutan dan akan dihentikan jika sesuai dengan kebutuhan dan dirasa sudah cukup. 


\section{Alat Pengumpul Data}

Alat pengumpul data dalam penelitian ini adalah tes buatan guru yang fungsinya adalah: (1) untuk menentukan seberapa baik siswa telah menguasai bahan pelajaran yang diberikan dalam waktu tertentu, (2) untuk menentukan apakah suatu tujuan telah tercapai, dan (3) untuk memperoleh suatu nilai (Arikunto, Suharsimi, 2002:149). Sedangkan tujuan dari tes adalah untuk mengetahui ketuntasan belajar siswa secara individual maupun secara klasikal. Di samping itu untuk mengetahui letak kesalahankesalahan yang dilakukan siswa sehingga dapat dilihat dimana kelemahannya, khususnya pada bagian mana TPK yang belum tercapai. Untuk memperkuat data yang dikumpulkan maka juga digunakan metode observasi (pengamatan) yang dilakukan oleh teman sejawat untuk mengetahui dan merekam aktivitas guru dan siswa dalam proses belajar mengajar.

\section{Analisis Data}

Dalam rangka menyusun dan mengolah data yang terkumpul sehingga dapat menghasilkan suatu kesimpulan yang dapat dipertanggungjawabkan, maka digunakan analisis data kuantitatif dan pada metode observasi digunakan data kualitatif. Cara penghitungan untuk mengetahui ketuntasan belajar siswa dalam proses belajar mengajar sebagai berikut.

1. Merekapitulasi hasil tes

2. Menghitung jumlah skor yang tercapai dan prosentasenya untuk masing-masing siswa dengan menggunakan rumus ketuntasan belajar seperti yang terdapat dalam buku petunjuk teknis penilaian yaitu siswa dikatakan tuntas secara individual jika mendapatkan nilai minimal 65 , sedangkan secara klasikal dikatakan tuntas belajar jika jumlah siswa yang tuntas secara individu mencapai $85 \%$ yang telah mencapai daya serap lebih dari sama dengan $65 \%$.

3. Menganalisa hasil observasi yang dilakukan oleh guru sendiri selama kegiatan belajar mengajar berlangsung.
HASIL PENELITIAN DAN PEMBAHASAN A. Hubungan Pembelajaran Model Kolaborasi dengan Ketuntasan Belajar

Suatu pokok bahasan atau sub pokok bahasan dianggap tuntas secara klasikal jika siswa yang mendapat nilai 65 lebih dari atau sama dengan $85 \%$, sedangkan seorang siswa dinyatakan tuntas belajar pada pokok bahasan atau sub pokok bahasan tertentu jika mendapat nilai minimal 65 .

1. Siklus I

a.Tahap Perencanaan

Pada tahap ini peneliti mempersiapkan perangkat pembelajaran yang terdiri dari rencana pelajaran 1 , soal tes formatif 1 dan alatalat pengajaran yang mendukung. Selain itu juga dipersiapkan lembar observasi pengelolaan model pembelajaran KOLABORASI , dan lembar observasi aktivitas guru dan siswa.

b.Tahap Kegiatan dan Pelaksanaan

Pelaksanaan kegiatan belajar mengajar untuk siklus I dilaksanakan pada tanggal 4 Maret 2005 di Kelas VI jumlah siswa 22 siswa. Dalam hal ini peneliti bertindak sebagai pengajar. Adapun proses belajar mengajar mengacu pada rencana pelajaran yang telah dipersiapkan. Pengamatan (observasi) dilaksanakan bersamaan dengan pelaksanaan belajar mengajar.

Pada akhir proses belajar mengajar siswa diberi tes formatif I dengan tujuan untuk mengetahui tingkat keberhasilan siswa dalam proses belajar mengajar yang telah dilakukan. Adapun data hasil penelitian pada siklus I adalah sebagai berikut.

Tabel 4.1. Rekapitulasi Hasil Tes Formatif Siswa Pada Siklus I

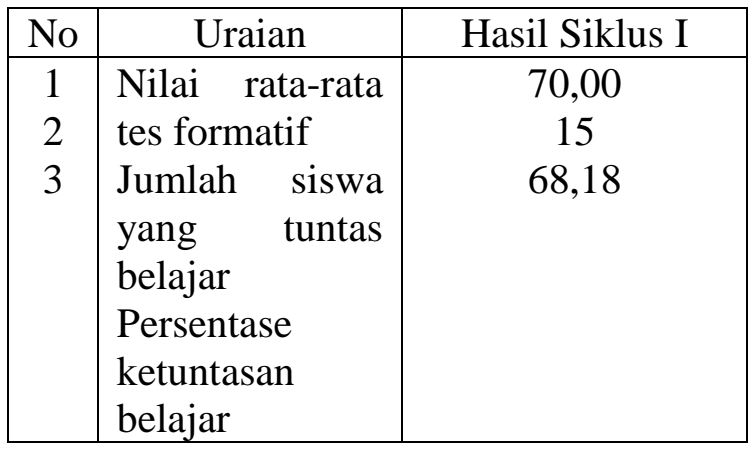


Dari tabel di atas dapat dijelaskan bahwa dengan menerapkan pembelajaran model Kolaborasi diperoleh nilai rata-rata prestasi belajar siswa adalah 70,00 dan ketuntasan belajar mencapai $68,18 \%$ atau ada 15 siswa dari 22 siswa sudah tuntas belajar. Hasil tersebut menunjukkan bahwa pada siklus pertama secara klasikal siswa belum tuntas belajar, karena siswa yang memperoleh nilai $\geq 65$ hanya sebesar $68,18 \%$ lebih kecil dari persentase ketuntasan yang dikehendaki yaitu sebesar $85 \%$. Hal ini disebabkan karena siswa masih merasa baru dan belum mengerti apa yang dimaksudkan dan digunakan guru dengan menerapkan pembelajaran model Kolaborasi.

c.Refleksi

Dalam pelaksanaan kegiatan belajar mengajar diperoleh informasi dari hasil pengamatan sebagai berikut:

1) Guru kurang maksimal dalam memotivasi siswa dan dalam menyampaikan tujuan pembelajaran

2) Guru kurang maksimal dalam pengelolaan waktu

3) Siswa kurang aktif selama pembelajaran berlangsung

d. Refisi

Pelaksanaan kegiatan belajar mengajar pada siklus I ini masih terdapat kekurangan, sehingga perlu adanya revisi untuk dilakukan pada siklus berikutnya.

1) Guru perlu lebih terampil dalam memotivasi siswa dan lebih jelas dalam menyampaikan tujuan pembelajaran. Dimana siswa diajak untuk terlibat langsung dalam setiap kegiatan yang akan dilakukan.

2) Guru perlu mendistribusikan waktu secara baik dengan menambahkan informasiinformasi yang dirasa perlu dan memberi catatan.

3) Guru harus lebih terampil dan bersemangat dalam memotivasi siswa sehingga siswa bisa lebih antusias.

2. Siklus II

a.Tahap perencanaan

Pada tahap ini peneliti mempersiapkan perangkat pembelajaran yang terdiri dari rencana pelajaran 2 , soal tes formatif 2 dan alatalat pengajaran yang mendukung.

b. Tahap kegiatan dan pelaksanaan

Pelaksanaan kegiatan belajar mengajar untuk siklus II dilaksanakan pada tanggal 11 Maret 2005 di Kelas VI dengan jumlah siswa 22 siswa. Dalam hal ini peneliti bertindak sebagai pengajar. Adapun proses belajar mengajar mengacu pada rencana pelajaran dengan memperhatikan revisi pada siklus I, sehingga kesalahan atau kekurangan pada siklus I tidak terulang lagi pada siklus II. Pengamatan (observasi) dilaksanakan bersamaan dengan pelaksanaan belajar mengajar.

Pada akhir proses belajar mengajar siswa diberi tes formatif II dengan tujuan untuk mengetahui tingkat keberhasilan siswa dalam proses belajar mengajar yang telah dilakukan. Instrumen yang digunakan adalah tes formatif II. Adapun data hasil penelitian pada siklus II adalah sebagai berikut.

Tabel 4.2. Rekapitulasi Hasil Tes Formatif Siswa Pada Siklus II

\begin{tabular}{|c|l|c|}
\hline No & \multicolumn{1}{|c|}{ Uraian } & $\begin{array}{c}\text { Hasil Siklus } \\
\text { II }\end{array}$ \\
\hline 1 & Nilai rata-rata tes & 77,73 \\
2 & formatif & 17 \\
3 & Jumlah siswa yang & 79,01 \\
& $\begin{array}{l}\text { tuntas belajar } \\
\text { Persentase ketuntasan } \\
\text { belajar }\end{array}$ \\
\hline
\end{tabular}

Dari tabel di atas diperoleh nilai rata-rata prestasi belajar siswa adalah 77,73 dan ketuntasan belajar mencapai 79,01\% atau ada 17 siswa dari 22 siswa sudah tuntas belajar. Hasil ini menunjukkan bahwa pada siklus II ini ketuntasan belajar secara klasikal telah mengalami peningkatan sedikit lebih baik dari siklus I. Adanya peningkatan hasil belajar siswa ini karena setelah guru menginformasikan bahwa setiap akhir pelajaran akan selalu diadakan tes sehingga pada pertemuan berikutnya siswa lebih termotivasi untuk belajar. Selain itu siswa juga sudah mulai mengerti apa yang dimaksudkan dan diinginkan guru dengan menerapkan pembelajaran model Kolaborasi. 
c. Refleksi

Dalam pelaksanaan kegiatan belajar diperoleh informasi dari hasil pengamatan sebagai berikut.

1) Memotivasi siswa

2) Membimbing siswa merumuskan kesimpulan/menemukan konsep

3) Pengelolaan waktu

d.Revisi Rancangan

Pelaksanaan kegiatan belajar pada siklus II ini masih terdapat kekurangan-kekurangan. Maka perlu adanya revisi untuk dilaksanakan pada siklus II antara lain:

1) Guru dalam memotivasi siswa hendaknya dapat membuat siswa lebih termotivasi selama proses belajar mengajar berlangsung.

2) Guru harus lebih dekat dengan siswa sehingga tidak ada perasaan takut dalam diri siswa baik untuk mengemukakan pendapat atau bertanya.

3) Guru harus lebih sabar dalam membimbing siswa merumuskan kesimpulan/menemukan konsep.

4) Guru harus mendistribusikan waktu secara baik sehingga kegiatan pembelajaran dapat berjalan sesuai dengan yang diharapkan.

5) Guru sebaiknya menambah lebih banyak contoh soal dan memberi soal-soal latihan pada siswa untuk dikerjakan pada setiap kegiatan belajar mengajar.

3.Siklus III

a. Tahap perencanaan

Pada tahap ini peneliti mempersiapkan perangkat pembelajaran yang terdiri dari rencana pelajaran 3 , soal tes formatif 3 dan alatalat pengajaran yang mendukung.

b. Tahap kegiatan dan pengamatan

Pelaksanaan kegiatan belajar mengajar untuk siklus III dilaksanakan pada tanggal 18 .... 2005 di Kelas ... dengan jumlah siswa 22 siswa. Dalam hal ini peneliti bertindak sebagai pengajar. Adapun proses belajar mengajar mengacu pada rencana pelajaran dengan memperhatikan revisi pada siklus II, sehingga kesalahan atau kekurangan pada siklus II tidak terulang lagi pada siklus III. Pengamatan (observasi) dilaksanakan bersamaan dengan pelaksanaan belajar mengajar.

Pada akhir proses belajar mengajar siswa diberi tes formatif III dengan tujuan untuk mengetahui tingkat keberhasilan siswa dalam proses belajar mengajar yang telah dilakukan. Instrumen yang digunakan adalah tes formatif III. Adapun data hasil penelitian pada siklus III adalah sebagai berikut.

Tabel 4.3. Hasil Formatif Siswa Pada Siklus III

\begin{tabular}{|c|l|c|}
\hline No & \multicolumn{1}{|c|}{ Uraian } & $\begin{array}{c}\text { Hasil Siklus } \\
\text { III }\end{array}$ \\
\hline 1 & Nilai rata-rata tes & 82,73 \\
2 & formatif & 19 \\
3 & $\begin{array}{l}\text { Jumlah siswa yang } \\
\text { tuntas belajar } \\
\text { Persentase ketuntasan } \\
\text { belajar }\end{array}$ & 86,36 \\
\hline
\end{tabular}

Berdasarkan tabel di atas diperoleh nilai rata-rata tes formatif sebesar 82,73 dan dari 22 siswa telah tuntas sebanyak 19 siswa dan 3 siswa belum mencapai ketuntasan belajar. Maka secara klasikal ketuntasan belajar yang telah tercapai sebesar 86,36\% (termasuk kategori tuntas). Hasil pada siklus III ini mengalami peningkatan lebih baik dari siklus II. Adanya peningkatan hasil belajar pada siklus III ini dipengaruhi oleh adanya peningkatan kemampuan guru dalam menerapkan pembelajaran model Kolaborasi sehingga siswa menjadi lebih terbiasa dengan pembelajaran seperti ini sehingga siswa lebih mudah dalam memahami materi yang telah diberikan.

c.Refleksi

Pada tahap ini akan dikaji apa yang telah terlaksana dengan baik maupun yang masih kurang baik dalam proses belajar mengajar dengan penerapan pembelajaran model Kolaborasi. Dari data-data yang telah diperoleh dapat diuraikan sebagai berikut:

1) Selama proses belajar mengajar guru telah melaksanakan semua pembelajaran dengan baik. Meskipun ada beberapa aspek yang belum sempurna, tetapi persentase pelaksanaannya untuk masing-masing aspek cukup besar. 
2) Berdasarkan data hasil pengamatan diketahui bahwa siswa aktif selama proses belajar berlangsung.

3) Kekurangan pada siklus-siklus sebelumnya sudah mengalami perbaikan dan peningkatan sehingga menjadi lebih baik

4) Hasil belajar siswa pada siklus III mencapai ketuntasan.

d. Revisi Pelaksanaan

Pada siklus III guru telah menerapkan pembelajaran model Kolaborasi dengan baik dan dilihat dari aktivitas siswa serta hasil belajar siswa pelaksanaan proses belajar mengajar sudah berjalan dengan baik. Maka tidak diperlukan revisi terlalu banyak, tetapi yang perlu diperhatikan untuk tindakan selanjutnya adalah memaksimalkan dan mempertahankan apa yang telah ada dengan tujuan agar pada pelaksanaan proses belajar mengajar selanjutnya penerapan model pengajaran kolaborasi dapat meningkatkan proses belajar mengajar sehingga tujuan pembelajaran dapat tercapai

B. Pembahasan

1. Ketuntasan Hasil Belajar Siswa

Melalui hasil penelitian ini menunjukkan bahwa pembelajaran model Kolaborasi memiliki dampak positif dalam meningkatkan prestasi belajar siswa. Hal ini dapat dilihat dari semakin mantapnya pemahaman siswa terhadap materi yang disampaikan guru (ketuntasan belajar meningkat dari siklus I, II, dan III) yaitu masingmasing 68,18\%, 79,01\%, dan 86,36\%. Pada siklus III ketuntasan belajar siswa secara klasikal telah tercapai.

2. Kemampuan Guru dalam Mengelola Pembelajaran

Berdasarkan analisis data, diperoleh aktivitas siswa dalam proses belajar mengajar dengan menerapkan model pengajaran kolaborasi dalam setiap siklus mengalami peningkatan. Hal ini berdampak positif terhadap prestasi belajar siswa yaitu dapat ditunjukkan dengan meningkatnya nilai rata-rata siswa pad setiap siklus yang terus mengalami peningkatan.

3. Aktivitas Siswa Dalam Pembelajaran

Berdasarkan analisis data, diperoleh aktivitas siswa dalam proses pembelajaran PAI Jurnal Pendidikan Mandala pada pokok bahasan kisah nabi Ibrahim a.s, dan nabi Ismail a.s dengan model pengajaran kolaborasi yang paling dominan adalah, mendengarkan/memperhatikan penjelasan guru, dan diskusi antar siswa/antara siswa dengan guru. Jadi dapat dikatakan bahwa aktivitas siswa dapat dikategorikan aktif.

Sedangkan untuk aktivitas guru selama pembelajaran telah melaksanakan langkahlangkah kegiatan belajar mengajar dengan menerapkan pengajaran konstekstual model pengajaran berbasis masalah dengan baik. Hal ini terlihat dari aktivitas guru yang muncul di antaranya aktivitas membimbing dan mengamati siswa dalam menemukan konsep, menjelaskan materi yang sulit, memberi umpan balik/evaluasi/tanya jawab dimana prosentase untuk aktivitas di atas cukup besar.

\section{KESIMPULAN}

Berdasarkan hasil penelitian yang telah dipaparkan selama tiga siklus, hasil seluruh pembahasan serta analisis yang telah dilakukan dapat disimpulkan model pengajaran kolaborasi dapat meningkatkan kualitas pembelajaran PAI. Pembelajaran model Kolaborasi memiliki dampak positif dalam meningkatkan prestasi belajar siswa yang ditandai dengan peningkatan ketuntasan belajar siswa dalam setiap siklus, yaitu siklus I $(68,18 \%)$, siklus II $(79,01 \%)$, siklus III (86,36\%). Model kolaborasi mempunyai pengaruh positif, yaitu dapat meningkatkan motivasi belajar siswa.

\section{DAFTAR PUSTAKA}

Ali, Muhammad. 1996. Guru Dalam Proses Belajar Mengajar. Bandung: Sinar Baru Algesindon.

Arikunto, Suharsimi. 1993. Manajemen Mengajar Secara Manusiawi. Jakarta: Rineksa Cipta.

Arikunto, Suharsimi. 2001. Dasar-dasar Evaluasi Pendidikan. Jakarta: Bumi Aksara.

Arikunto, Suharsimi. 2002. Prosedur Penelitian Suatu Pendekatan Praktek. Jakarta: Rineksa Cipta. 
Azhar, Lalu Muhammad. 1993. Proses Belajar Mengajar Pendidikan. Jakarta: Usaha Nasional.

Daroeso, Bambang. 1989. Dasar dan Konsep Pendidikan Moral Pancasila. Semarang: Aneka Ilmu.

Djamarah, Syaiful Bahri. 2002. Psikologi Belajar. Jakarta: Rineksa Cipta.

Djamarah, Syaiful Bahri. 2002. Strategi Belajar Mengajar. Jakarta: Rineksa Cipta.

Hadi, Sutrisno. 1982. Metodologi Research, Jilid 1. Yogyakarta: YP. Fak. Psikologi UGM.

Hamalik, Oemar. 2002. Psikologi Belajar dan Mengajar. Bandung: Sinar Baru Algesindo.

Hasibuan K.K. dan Moerdjiono. 1998. Proses Belajar Mengajar. Bandung: Remaja Rosdakarya.

Isnaini, LMY. 2012. Pembinaan Olahraga Dalam Pembentukan Karakter. Surabaya. $9786027508 \quad 75-0 \quad 12(978$ 6027508 75-0), 12 vol.

Isnaini, LMY., Hananingsih, W. 2018. Persepsi dan Motivasi Mahasiswa Pada UKM Bola Basket di Universitas Nahdlatul Ulama NTB. JISIP (Jurnal Ilmu Sosial dan Pendidikan) 2 (1).

Isnaini, LMY., Soegiyanto., Sugiharto., Sulaiaman. Effect of Hyperbaric Oxygen and Vital Capacity of Lungs on Maximum Aerobic Capacity and Anaerobic Capacity and Anaerobic Endurance to Basketball Players. International Journal of Pharmaceutical Research. Volume 11, issue 3, July-Sept, 2019

Margono. 1997. Metodologi Penelitian Pendidikan. Jakarta. Rineksa Cipta.

Masriyah. 1999. Analisis Butir Tes. Surabaya: Universitas Press.

Ngalim, Purwanto M. 1990. Psikologi Pendidikan. Bandung: PT. Remaja Rosdakarya.

Nur, Moh. 2001. Pemotivasian Siswa untuk Belajar. Surabaya: University Press. Univesitas Negeri Surabaya.
Rustiyah, N.K. 1991. Strategi Belajar Mengajar. Jakarta: Bina Aksara.

Sardiman, A.M. 1996. Interaksi dan Motivasi Belajar Mengajar. Jakarta: Bina Aksara.

Soekamto, Toeti. 1997. Teori Belajar dan Model Pembelajaran. Jakarta: PAU-PPAI, Universitas Terbuka.

Sukidin, dkk. 2002. Manajemen Penelitian Tindakan Kelas. Surabaya: Insan Cendekia.

Surakhmad, Winarno. 1990. Metode Pengajaran Nasional. Bandung: Jemmars.

Suryosubroto, B. 1997. Proses Belajar Mengajar di Sekolah. Jakarta: PT. Rineksa Cipta.

Syah, Muhibbin. 1995. Psikologi Pendidikan, Suatu Pendekatan Baru. Bandung: Remaja Rosdakarya.

Usman, Moh. Uzer. 2001. Menjadi Guru Profesional. Bandung: Remaja Rosdakarya. 